\title{
Species Richness of Macrofungi and Ethnomycological Studies in Chitlang, Makwanpur, Central Nepal
}

Priyanka Shah*, Hari Prasad Aryal and Tej Bahadur Darji

Central Department of Botany, Tribhuvan University, Kirtipur, Kathmandu, Nepal

*Corresponding author Email:priyankashah2336@gmail.com

(Submitted on August 23, 2020; Accepted on December 10, 2020)

\begin{abstract}
Macrofungi, the most diverse groups of organisms on earth constitute a significant part of terrestrial ecosystems. Wild edible mushrooms are important non-timber forest products, a potential source of income in terms local trade and export. Inspite of their significant role in ecosystems they are facing threat of extinction due to environment destruction. The main objective of this research is to explore the species richness and indigenous knowledge of macrofungi in the study area. The study was conducted from July to September 2019 in Chitlang, Makwanpur. Field investigation was done by using systematic random sampling where plot of $10 \times 10 \mathrm{~m}^{2}$ were layed in line transect at $1600 \mathrm{~m}, 1800 \mathrm{~m}$ and $2000 \mathrm{~m}$. A participatory rural appraisal technique was adopted to obtain information largely on ethnomycological aspects. This investigation explored the diversity of higher fungi with their identification, documentation and utilization. The study reported 129 species belonging to 41 families, 70 genera and 13 orders. The research revealed the use of 13 species of mushroom by the local respondents. Species richness of macrofungi increases with increase in soil moisture, litter cover, soil carbon but the relation between canopy cover and species richness was not significant.
\end{abstract}

KEYWORDS: Altitudinal gradients, phosphate solubilization, subtropical ecosystem.

\section{INTRODUCTION}

Fungi represent the diverse group of organisms that ranges from microscopic forms to large mushrooms. These microbes convert dead organic matter into protein, minerals and alkaloids and number of bioactive components. Macrofungi are the members of Phylum Ascomycota and Basidiomycota having hypogeous or epigeous distinctive fruiting bodies. The diversity of different groups of fungi varies from region to region and is higher in the subtropical and temperate regions in comparison to the tropical, subalpine and alpine zones (Adhikari, 2000). Presence of varied phytogeographic factors in Nepal plays an imperative role in the growth and diversity of fungi which inturn have made the country a natural house for mycodiversity. They make among the most diverse groups of organisms on our planet.The world over it is estimated that around 2.2-3.8 million fungi including mushrooms exist in nature out of which only about 7\% are known (Hawksworth and Luking, 2017). However, GBIF.org (2020) estimated the global fungal species at about 19,056,194. Amongst these the estimated number of mushrooms is reported to be about $1,50,000$ to $1,60,000$ species, out of which approximately 16000 mushroom species are reported to have been described (Zied and Pardo-Gimenez, 2017).

The history of assessment of macrofungal diversity in Nepal dates back to mid of $19^{\text {th }}$ century when J D Hooker explored the mushrooms of East Nepal from 1848-1854 in a botanical survey. Till date from Nepal 357 genera (72 genera of Ascomycota and 285 genera of Basidiomycota) and 1,291 species (165 species of Ascomycota and 1,126 species of Basidiomycota) belonging to 108 families have been documented (Devkota and Aryal, 2020).

Ethnomycology is the study of historical uses and sociological aspects of fungi which is considered as subfield of ethnobotany. Wasson (1969) is credited for coining the term "Ethnomycology". Mushrooms have been used by the ancient people and primitive tribes from coon's ages. The archaeological record reveals edible species associated with people living 13000 years ago in Chile (Rojas and Mansur, 1955). In last few decades, there has been increasing worldwide attention on the use of wild edible fungi (FAO, 2004). In Nepal 1.7 to 6.5 tons of morels are exported with total value of 105,000 to 400,000 US $\$$ (Olsen, 2004). Romans believed mushrooms to have properties that could produce super human strength, help in finding lost objects and leads the soul to the realm of the Gods (Grube et al., 2001). Edible mushrooms contain high level of dietary fiber, substantial amount of protein, vitamins and minerals but are low in fat. They also have various properties for health benefits such as antioxidative, antitumor and hypercholesterolic effects (Cheung, 2010). Wild edible macrofungi are acknowledged not only for texture and flavor but also for their chemical and nutritional characteristics (Tapwal et al., 2013) and are also considered as best alternative for meat and fish. The knowledge about the utilization of wild mushrooms varies from culture, beliefs and region that pass within generation. This type of study helps to record the folklore of fungi by a specific local community and aids in evaluation of the services provided by wild fungi which will be useful in conservation plans.

\section{MATERIALSAND METHODS}

Study area: The study was conducted in Chitlang-9, Thaha Municipality, Makwanpur district, Province no. 3, Central Nepal (Fig. 1), located in the south west of Kathmandu valley in mid-hills called Mahabharat range. Its geographical location of the area is $85^{\circ} 17^{\prime} 804^{\prime \prime}$ to $85^{\circ} 18^{\prime} 155^{\prime \prime} \mathrm{E}$ longitude and $27 \mathrm{o} 65^{\prime} 665^{\prime}$ " to $27^{\circ} 65^{\prime} 672^{\prime \prime} \mathrm{N}$ latitude. This region covers mid hills area which ranges from 1750 to 2000 meters above sea level. The forest covers the area of 196 hectares. The average annual rainfall is 136-216 mm (DHM, 2018). Study was conducted in two types of forest, i.e. Chandragiri Community Forest and Bicharthok Leasehold Forest. The dominant plant species in the area are represented by Acer oblongum, Alnus nepalensis, Berberis aristata, Betula alnoides, Castanopsis indica, Celtis australis, Juglans regia, 
Machilus odoratissima, Myrica esculenta, Prunus cerasoides, Pinus wallichiana, Pyracantha crenulata, Pyrus pashia, Quercus lamellosa, Q. glauca, Q. semecarpifolia, Rhododendron arborerium, Rhus javanica, Rubus ellipticus and Syzygium cumini in the Chandragiri Community Forest; and Celtis australis, Prunus cerasoides, Pinus wallichiana, Quercus lamellose, Q. lanata, Q. glauca, Q. tribuloides and Rhododendron arborerium in managed Bicharthok Leasehold Forest.

Sampling design: The survey was conducted from July to September, 2019. A detailed study of macrofungi was made by using systematic random sampling where plot of size $10 \times 10 \mathrm{~m}^{2}$ were sampled in line transect. Three line transect were made in equal distance in $1600 \mathrm{~m}, 1800 \mathrm{~m}$ and $2000 \mathrm{~m}$ above sea level (asl )in both forests. In each transect, 6 plots were taken and in all total 18 plots were sampled in each forest type at a distance of $20 \mathrm{~m}$ (O'Hanlon and Harrington, 2012) along 3 transect. Soil samples were collected from the four corners and the center of each plot in both study sites at the depth of $10 \mathrm{~cm}$ using a soil digger (Zobel et al., 1987). These samples were mixed homogenously to make composite sample. Tree canopy cover and litter cover (in percentage) were estimated visually.
Ethnomycological Survey: A participatory rural appraisal (PRA) survey was conducted with local people aimed at getting information largely on mycodiversity aspects (Freudenberg, 2011). Ethnomycological data was collected randomly using combined semi-structured questionnaire, participatory discussions and field observations. The oral interview involved mainly the available household head, sometimes assisted by other members. The interview campaign involved 60 informants, all randomly selected. The questions were focused basically on the informant's knowledge concerning the different uses of wild mushrooms including local name of the mushroom, types of mushroom (edible or poisonous) and uses of mushroom (as food value or medicinal value or cultural value) among the different tribal communities. The sites of mushroom collection and other related information was ascertained from the villagers in the locality. Required materials were used on the basis of standard protocols (Brundrett et al., 1996).

Sample Collection: Samples were photographed in their natural habitat and their morphological characters were noted before collection. The broken, rotten and insect eaten species were discarded. The developmental stages of basidiocarp

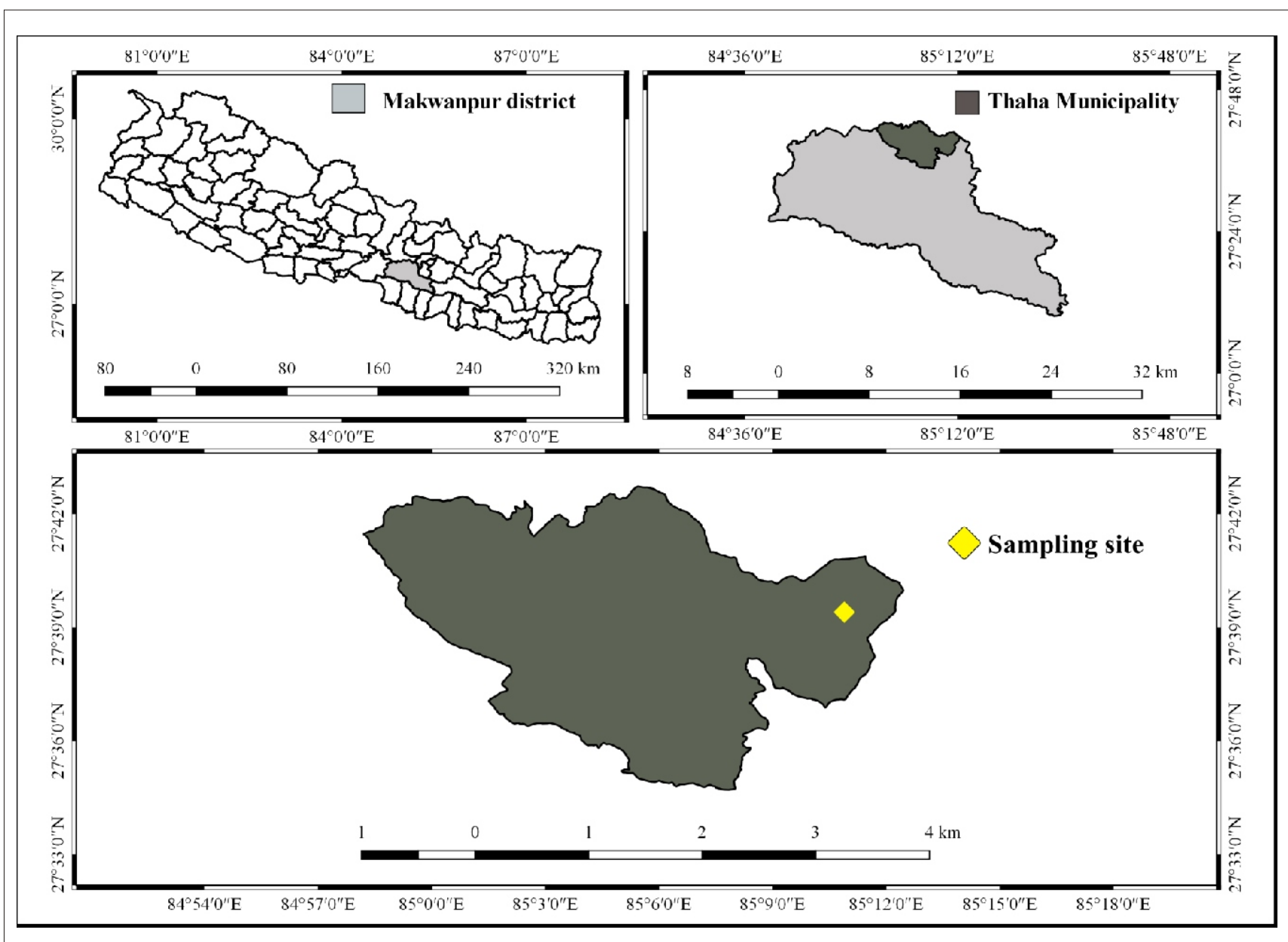

Fig.1. Map of study area: (a) Nepal showing Makwanpur district; (b) Makwanpur district showing Thaha municipality; (c) Thaha municipality showing Chitlang. 
were picked carefully by digging with knife or digger. Three visits were made for the collection of macrofungi and 3 sets of specimens were collected. Specific collection number was given to each species. Almost all species were preserved liquid and dry depending on the nature of mushroom (fleshy or woody). The specimens which are hard to touch were sun dried for some time to prevent rotting and placed in paper bags with some Napthalene balls/1,4 paradichlorobenzene to prevent from pest and insects (Atri et al., 2005). The fleshy specimens were preserved in bottle in the mixture of distilled water, alcohol and formalin in 70:25:5 concentrations (Anisworth, 1971). Spore deposits were taken during sample collection. The ecological parameters, viz. altitude, vegetation composition, soil type, humidity and temperature were also recorded.

Identification: Some macrofungi were identified in-situ. Identification was done based on diagnostic morphological characteristics and microscopic examinations. The samples and photographs were identified with the help of mushroom expert from Central Department of Botany and with the help of standard literatures (Pacioni, 1985; Singer, 1986; Thind, 1961; Phillips, 1981; Corner, 1970) and web surfing (Index fungorum; Jostor.org; Mycobank.org; biodiversity library.org). The collected species were compared with the specimen present in Applied Mycology and Plant Pathology Unit, Tribhuvan University for identification. The classification followed is as given by (Kuo, 2014).

Laboratory Study: In laboratory, soil $\mathrm{pH}$, soil moisture and soil carbon were estimated by following Zobel et al., (1987). The voucher specimens were deposited in the Plant Pathology Unit, Central Department of Botany.

Data analysis: The data obtained from the field assessment was analyzed with the help of SPSS (Statistical Package for Social Sciences) version 23. The relation between environmental variables $(\mathrm{pH}$, moisture, canopy cover, carbon and litter cover) with species richness of mushroom was analyzed using correlation - regression using SPSS ver.23. Ordination technique was used to study the pattern of speciesenvironment relationship. To analyze the simultaneous effect of environmental variables on the macrofungal diversity, Detrended Correspondence Analysis (DCA) was carried out. The value of gradient length being less than 2.5 , checked the data to perform the canonical correspondence analysis (CCA) so, environmental variables were fitted in DCA plot. Ordination was carried out from R studio (version 3.5.1) ( R Core Team 20)

\section{RESULTS}

The study explored 129 species of mushrooms in the study site which belongs to 41 families, 70 genera and 13 orders. The study area was rich in mushroom diversity which is primarily due to the favorable environmental condition for macrofungal growth. Agaricales was found as the largest order with 56 species followed by Russulales with 21 species, Boletales with 19 species, Polyporales with 15 species, Hymenochaetales with 4 species, Peizizales with 4 species, Cantharellales with 2 species, Dacrymycetales with 2 species, Leotiales with 2 species and Amylocorticales, Helotiales, Tremellales,
Xylariales with 1 species each (Fig. 2). Among them 121 species of mushrooms belong to phylum Basidiomycota and 8 species belongs to phylum Ascomycota The mushrooms were collected from the two forest types, i.e. natural forest and managed forest. Out of 129 species of mushrooms, 77 species were recorded from managed forest whereas 106 species were recorded from natural forest (Table 1).

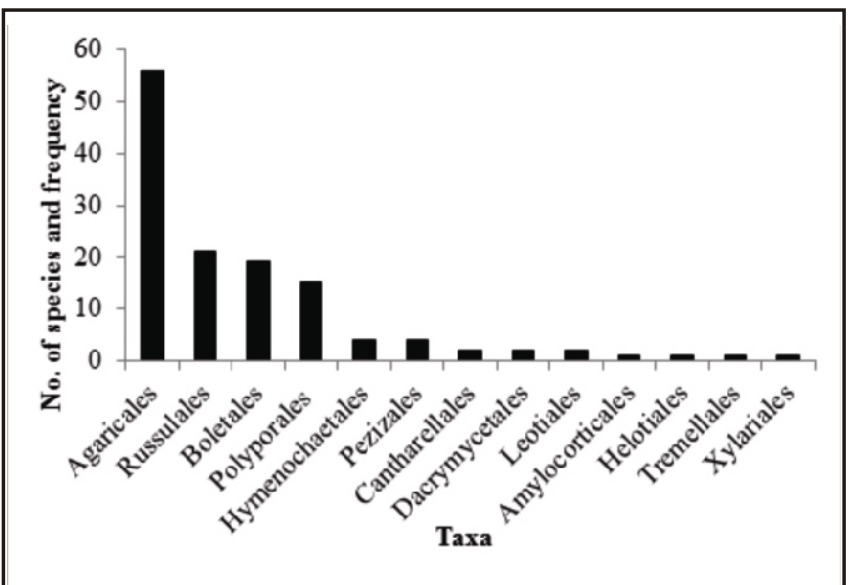

Fig.2. Number of macrofungal species with their orders

Table 1. Macrofungal diversity in different forest type

\begin{tabular}{|c|c|}
\hline Forest type & Species richness \\
\hline Chandragiri Community Forest (Natural forest) & 106 \\
\hline Bicharthok Leasehold Forest (Managed forest) & 77 \\
\hline
\end{tabular}

Relationship between species richness and environmental variables: The environmental variables like soil $\mathrm{pH}$, soil moisture, soil carbon, litter cover show positive trend of relationship with species richness of macrofungi (Fig. 3) but canopy cover show negative trend.

Pattern of species composition along environmental gradient: To analyze the simultaneous effect of independent variables on the dependent variables, multivariate technique was used. The effect of different environmental variables was analyzed in species density in each plot. Detrended correspondence analysis (DCA) was performed to explore the trend of sample species.

The DCA figure (Fig.4) showed that the appearance of mushroom species like Coriolus versicolor, Psilocybe coprophila, Russula virescens were high towards high canopy cover. Coltricia perennis shows negative relation with $\mathrm{pH}$ while Trichaptum byssogenum shows positive relation with $\mathrm{pH}$ (Fig. 4). The species like Leccinum scabrum, Tyromyces caesius and Hygrocybe cuspidata were carbon and litter loving species as shown in the ordination.

Indigenous knowledge: During ethnomycological survey all together 60 people were interviewed, among them 32 were men and 28 were women. On the basis of the information collected, $10 \%$ respondents were below 30 years, $40 \%$ respondents were between 30 to 45 years, $25 \%$ respondents 

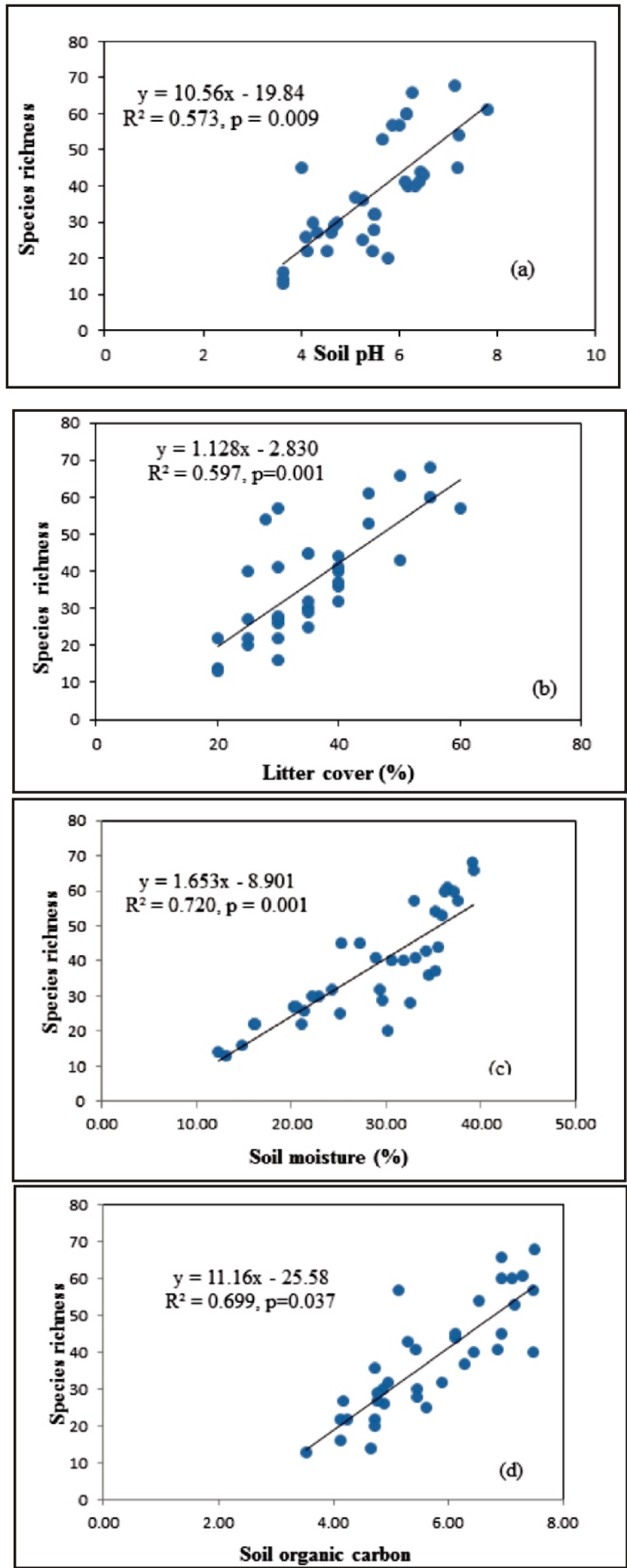

Fig. 3 (a-d). Variation in species richness of macrofungi with (a) soil pH; (b) litter covers; (c) soil moisture; (d) soil carbon

were between $45-60$ years and remaining $25 \%$ were above 60 years. Out of total respondents, $49 \%$ were from Tamang

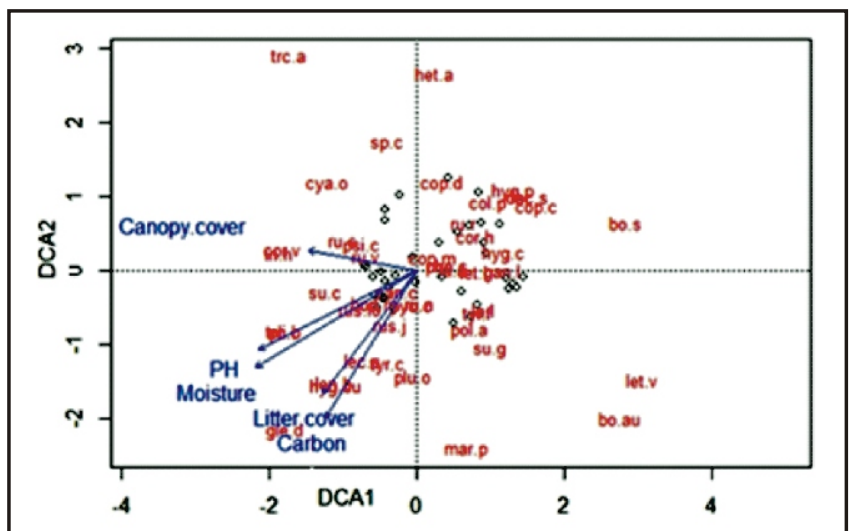

Fig.4. DCA plot for macrofungi along with environmental variables

communities followed by $23 \%$ from Newar communities, $20 \%$ from Brahmin communities and 5\% respondents were from Chhetri communities. Among the total number of respondents, 42 used to collect mushrooms for food, 10 used to collect for food and medicinal purpose, 6 used to collect for food and religious value and 2 used to collect for food, medicinal and religious purposes (Fig.5).



Fig. 5. Purpose of mushroom collection

Based on the survey, 27 respondents used to collect mushroom simply by hand picking method, 21 respondents used to collect by plucking, eight respondents used to collect mushroom by hand picking and plucking methods whereas only two respondents used to adopt digging method for collection and one respondent used to collect the mushroom by both hand picking and digging method. According to respondents the most favorable time for collection of mushroom is monsoon season but some of the respondent used to collect up to post monsoon season also.

Among the respondents, 21 respondents used to identify the edible mushroom by smelling, seven respondents used to identify by touching, nine respondents by colour of mushroom, seven respondents said that they used traditional techniques for identification, seven respondents identified edible mushrooms on the basis of their habitat or host plant and nine respondents used to identify by smelling and colour (Fig.6). 


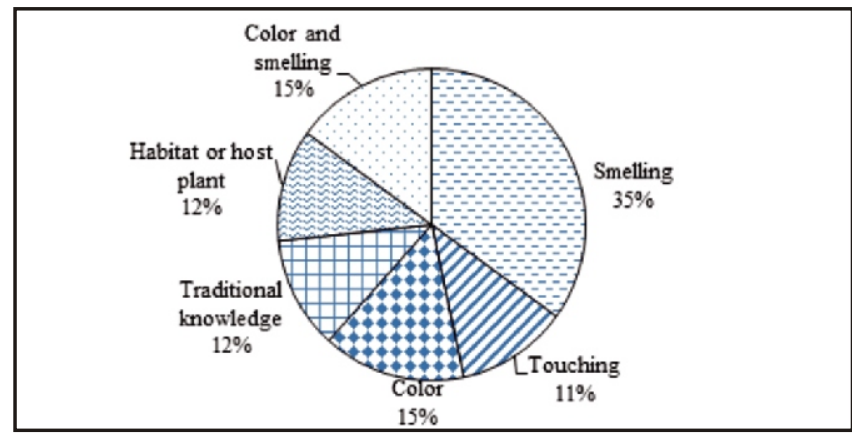

Fig.6. Way of identifying mushrooms by local people

Throughout the study time we found very interesting fact which made us to rethink on the status of local people and their perception on modern medical science. Among the respondents, 46 had never experienced the consumption of poisonous mushroom, 10 respondents said they used to have faeces of dogs after having poisonous mushroom and four respondents preferred to visit hospital after consumption of poisonous mushroom. The local people believed that mostly the mushrooms growing on the trees were edible and those growing on the soil as poisonous. They used to harvest the mushrooms from the bark of Quercus lanata (Banjha), Castanopsis indica (Katus), Celtis australis (Khari), Prunus cerasoides (Paiyu), Quercus glauca (Phalant), Myrica esculenta (Kafal), Syzygium cumini (Jamun) and Quercus semecarpifolia (Khasru).They adopted different methods before making mushroom recipe like boiling, burning in fire, frying, boiling with Zanthoxylum and Allium. They used mushrooms to prepare different recipe, like curry, mixed vegetables with soybean and potato, roast, soup and pickles. They used to prefer iron made utensils to prepare mushroom curry and vegetables; however other types like aluminium vessels, stainless steels and clay pots were also used to prepare mushroom recipe.

\section{DISCUSSION}

The species richness of mushrooms was found more in the natural forest than that of managed forest. The differences observed between the managed forest and natural forest is likely due to the differences in tree community composition. The managed forests generally consist of monoculture planting, whereas natural forest is a mixture of tree species. $\mathrm{Li}$ et al., (2018) showed that native forests contained a higher diversity of macrofungi compared with plantation forests. Brockerhoff et al., (2008) also showed evidence that native forests usually provide more suitable habitats than plantation forests.

Soil $\mathrm{pH}$ has been positively correlated with macrofungal diversity by Dang et al., (2018). Present study also documented significant relation between soil $\mathrm{pH}$ and species richness (Fig. 3a). Soil $\mathrm{pH}$ is reported to be a key factor in determining the soil fungal community composition by Zang et al., (2016). Fungi generally grow in well acidic conditions (Dix and Webster, 1995), but some fungi, e.g. Peziza grows in neutral to slightly alkaline conditions (Yamanaka, 2003). Litter plays two major roles in forest ecosystems: Firstly, plant litter is a fundamental part of nutrient and carbon cycling, and secondly, litter forms a protective layer on the soil surface that also regulates microclimatic conditions. Presently species richness of macrofungi was found increasing with the increase in litter cover (Fig. 3b). The results obtained during present study are in conformity with the findings of Eaton et al., (2004) and Sayer (2005). Moisture is an important factor in sporocarp production of macrofungi which plays an important role in the composition and productivity of fungal communities. Mushroom requires moisture to produce their fruit so wild mushrooms may disappear during dry weather and may appear when moisture levels improve. Species diversity was found higher with the increase in moisture, as moisture is one of the major factors influencing the fruiting of macrofungi (Fig.3c). This corresponds with the findings of Andrew et al., (2013) in the Mount Cameroon Region. Mushroom appears after the start of monsoon as the moisture content in the soil increases. This result corresponds with the finding of Dijk et al., (2003) and Bhandari and Jha (2017). In present study the richness of macrofungal species vary significantly with soil organic carbon. Species richness of macrofungi was found increasing with the increase in soil organic carbon (Fig. 3d). The results of the present study on this parameter correspond with the finding of Dang et al., (2018).

In the study site, it was found that local people of Chitlang used Pycnoporus cinnabarinus (Rate chyau) as remedy for treatment of mump disease; ear pain, etc. and Laetioporus sulphuresus as vegetable and they also believed that it cures cancer. Ganoderma lucidum (Dhadu chyau) is being used by these people for decorative purpose and also as medicine, Trametes versicolor to cure wounds, Schizophyllum commune (Min chyau) in marriage ceremony, Laccaria laccata and Lactarius volemus (Dudhe chyau) as vegetable. Similar observations have been documented by Pandey et al., (2006). Local people of Chitlang used Zanthoxylum armatum (Timur) and Allium sativum (Lasun) to minimize possible poisoning along with vinegar. Vinegar addition is the worldwide followed method to minimize mushroom poisoning. Termitomyces clypeatus (Dhamire chyau) used as vegetable and for the treatment of fever and measles. Auricularia auricular-judae (Kane chyau) used as medicine, Lycoperdon pyriforme (Phusphuse chyau) and Coriolus hirstus (Kathe chyau) used for the treatment of wound, Pleurotus ostreatus (Kande chyau) used in marriage ceremony. Volvariella volvacea (Parale chyau) used in marriage and also used for treatment when a person suffers from abnormality in consciousness like hypertension and swelling, pain in ankles, foot, wrist, etc.

According to the respondents goats, deers, monkeys, rabbits, squirrels normally eat mushrooms in the forested areas. Local people preserved mushrooms by drying in sunlight and then packed in airtight vessels. They used plucking method for mushroom collection, knowingly or unknowingly they aid in regeneration of mushroom for next season since the mushroom spores remains in the residual part and the same species appear in the next season. According to the local people mushroom growing in soil started disappearing for the last ten years because the forest floor is occupied by Ageratina adenophora. Amanita hemibapha (Salle chyau/ 
Aande chyau) is one species which is reported to have disappeared during the last ten years.

The work related to ethnomycological studies have been undertaken in various parts of country. But Chitlang, which is a virgin area where no such work have been done previously. Based on the information gathered from the respondents the commonly consumed edible mushrooms in the area include Handi chyau (Russula nigricans), Mrige chyau (Lentinula edodes), Dhamire or Bagale chyau (Termitomyces clypeatus), Dudhe chyau (Lactarius piperatus, Lactarius volemus), Kane chyau (Auricularia auricular-judae), Giddhe chyau (Grifolia frondosa), Aande chyau (Amanita hemibapha), Thakre chyau (Hericium erinaceus), Jhari chyau (Laccaria laccata), Rate chyau (Laetioporus sulphuresus), Salle or Suntale chyau (Amanita caesarea), and Gobre chyau (Coprinus comatus). According to the respondents from the area surveyed, some of the most preferred mushrooms from edibility point of view are Dhamire or Bagale chyau (Termitomyces clypeatus), Mrige chyau (Lentulina edodes), Kande chyau (Pleurotus ostreatus), Parale chyau (Volvariella volvacea), Besarey chyau (Cantharellus cibarius) and Salle chyau (Amanita caesarea).

\section{ACKNOWLEDGEMENTS}

We would like to acknowledge University Grants Commission (UGC), Nepal for providing research grants to conduct this study. The authors are obliged to Central Department of Botany, Tribhuvan University for providing laboratory facilities. Sincere thanks are extended to the local peoples of Chitlang.

\section{REFERENCES}

Adhikari, M.K. 2000. Mushrooms of Nepal. (Ed.: Durrieu, G.), P.U. Printers, Kathmandu, Nepal. 236 pp.

Ainsworth, G.C. 1971. Ainsworth and Bisby's,Dictionary of Fungi. CMI, Kew Survey, England, 663.

Atri, N.S., Kaur, A. and Kour, H. 2005.Wild mushrooms collection and identification. In: Frontiers in Mushroom Biotechnology (Eds.: Rai, R.D., Upadhyay, R.C. and Sharma, S.R.). National Research Center for Mushroom, Chambaghat, Solan, India, 9-26.

Andrew, E.E.,Kinge, T.R., Tabi1, E.M., Thiobal, N. and Mih,A.M. 2013. Diversity and distribution of macrofungi (mushrooms) in the Mount Cameroon Region. J. Ecol. Nat. Environ. 5: 318-334.

Bhandari, B. and Jha, S.K. 2017. Comparative study of macrofungi in different patches of Boshan Community Forest in Kathmandu, Central Nepal. Botanica Orientalis- Journal of Plant Science 11: 43-48.

Brockerhoff, E.G., Jactel, H., Parrotta, J.A., Quine, C.P. and Sayer J. 2008. Plantation forest and biodiversity: Oxymoron or Opportunity? Biodivers. Conserv. 17: 925-951.

Brundrett, M., Bougher, N., Dell, B., Grave, T. and
Malajczuk, N. 1996.Working with Mycorrhizas in Forestry and Agriculture. Australian Centre for International Agricultural Research, Monograph 32, Canberra, Australia.

Cheung, P.C.K. 2010.The nutritional and health benefits of mushrooms. British Nutrition Foundation Nutrition Bulletin. 35: 292-299.

Corner, E.J.H. 1970. Supplement to a monograph of Clavaria and allied genera. Nova Hedwigia 33 Verlag von. J. Cramer.

Dang, P., Vu, N.H., Shen, Z., Liu, J., Zhao, F., Zhu, H., Yu, X. and Zhao, Z. 2018. Changes in soil fungal communities and vegetation following afforestation with Pinus tabulaeformis on the Loess Plateau. Ecosphere. 9: 1-17.

Devkota, S. and Aryal, H.P. 2020. Plant Diversity in Nepal (Eds.: Siwakoti, M., Jha, P.K., Rajbhandary, S. and Rai, S.K). Botanical Society of Nepal, Kathmandu, 41-54.

Dijk, H.V., Onguene, N.A. andKuyper, T.W. 2003. Knowledge and Utilization of Edible Mushrooms by Local Populations of the Rain Forest of South Cameroon. Ambio. 32:19-23.

DHM 2018. Department of Hydrology and Meteorology, Climatological and agro meteorological records of Nepal.Ministry of Environment, Science and Technology.

Dix, N.J. and Webster, J. 1995. Fungal Ecology.Chapman and Hall, London, UK.

Eaton, R.J., Barbercheck, M., Buford, M. and Smith, W. 2004. Effects of organic matter removal, soil compaction, and vegetation control on Collembolan populations. Pedobiologia 48: 121-128.

FAO (Food and Agriculture Organization) 2004. .Non wood forest products, wild edible fungi: a global overview of their use and importance. (Ed.: Boa, E.). FAO Publication Rome, 17-147.

Freudenberg, K.S. 2011. A Manual for CRS Field Workers and Partner. Maryland, USA.

GBIF.org. 2020.GBIF Home Page. Available from: https:// www.gbif.org [18 January 2020].

Grube, B.J., England, E.T. and Kao, Y.C. 2001. White bottom mushroom phytochemicals inhibit arometase activity and breast cancer cell proliferation. J. Nutr. 12: 3288-3293.

Hawksworth, D. and Lucking, R. 2017. Fungal diversity revisited: 2.2 to 3.8 million species. Microbiol. Spectr. 5: 1-17.

Kuo, M. 2014. Mushroom taxonomy: The big picture. Retrieved from the Mushroom Expert. Com. at 5.8.2019.

Li, H., Guo, J., Karunarathna, S.C., Ye, L., Xu, J., Hyde, K.D. 
and Mortimer, P.E. 2018. Native forests have higher diversity of macrofungi than comparable plantation forests in the Greater Mekong Subregion. Forests 9 : $1-14$.

Olsen, C.S. 2004. Quantification of the Trade in Medicinal and Aromatic plants in and from Nepal. Acta Hortic. 29-35p.doi:10.17660/ActaHortic.2005.678.3

O'Hanlon, R. and Harrington, T.J. 2012. Macrofungal diversity and ecology in four Irish forest types. Fungal Ecol. 5: 499-508.

Pacioni, G. 1985. The Mcdonald's encyclopedia of mushrooms and toadstools. Mcdonald and Co. Ltd., London. UK. 511 pp.

Pandey, N., Devkota, S., Christensen, M., and Budhathoki, U. 2006. Use of wild mushrooms among the Tamangs of Nepal. Nepal Journal of Science and Technology 7: $97-104$.

Phillips, R. 1981. Mushrooms and other Fungi of Great Britain and Europe. Pan Book Ltd. London, UK.288 pp.

Rojas, C. and Mansur E. 1995. Ecuador: informaciones generals sobre productos non madereros en Ecuador. In: Memoria consulta de expertos sobre productos forestales no madereros para America Latina y el Caribe. FAO Regional Office for Latin America and the Caribbean, Santiago (Chile), 208223 pp.

Sayer, E.J. 2005. Using experimental manipulation to assess the roles of leaf litter in the functioning of forest ecosystems. Biol. Rev. 80: 1-31.
Singer, R. 1986. The Agaricales in modern taxonomy (4 ${ }^{\text {th }}$ edition), Bishen Singh and Mahendra Pal Singh, Dehradun, India. 981pp.

Thind, K.S. 1961. The Clavariaceae of India. Indian Council of Agricultural Research, New Delhi, India.197 pp.

Wasson, G.R. 1969. Soma-Divine mushroom of immortality XIII, Hew Court Brace and world Inc., New York, USA.318 pp.

Yamanaka, T. 2003. The effect of $\mathrm{pH}$ on the growth of saprotrophic and ectomycorrhizal ammonia fungi in vitro. Mycologia 95: 584-589.

Zhang, T., Wang, N.F., Liu, H.Y., Zhang, Y.Q. and Yu, L.Y.2016. Soil pH is a Key Determinant of Soil Fungal Community Composition in the Ny-Ålesund Region, Svalbard (High Arctic). Front Microbiol. 7: $1-10$.

Zied, D. C. and Pardo-Gimï, A. 2017. Edible and medicinal mushrooms: technology and applications. John Wiley \& Sons. New York, U.S.A.

Zobel, D.B., Behan, M.J., Jha, P.K. and Yadav, P.K.R. 1987. A practical manual for ecology. Kathmandu, Nepal: Ratna Book Distributors.

\section{Websites:}

www.BiodiversityLibrary.org.com/ 17 June,2019

www.IndexFungorum.com/17 June,2019

www.Jstor.org.com/17 June,2019

Www.Mycobank.org.com/17 June,2019 